Journal of Hospitality and Tourism Management

http://journals.cambridge.org/JHT

Additional services for Journal of Hospitality and Tourism Management:

Email alerts: $\underline{\text { Click here }}$

Subscriptions: $\underline{\text { Click here }}$

Commercial reprints: Click here

Terms of use : $\underline{\text { Click here }}$

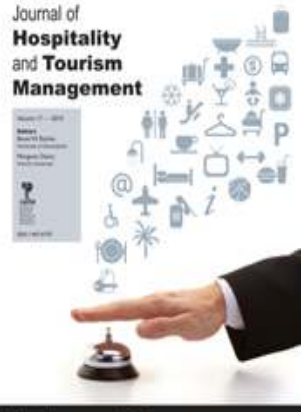

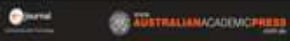

\title{
Critical Pedagogies: A Reflexive Approach to Knowledge Creation in Tourism and Hospitality Studies
}

Simone Fullagar and Erica Wilson

Journal of Hospitality and Tourism Management / Volume 19 / August 2012 / e2

DOI: 10.1017/jht.2012.3, Published online: 17 July 2012

Link to this article: http://journals.cambridge.org/abstract S183952601200003X

How to cite this article:

Simone Fullagar and Erica Wilson (2012). Critical Pedagogies: A Reflexive Approach to Knowledge Creation in Tourism and Hospitality Studies. Journal of Hospitality and Tourism Management, 19, e2 doi:10.1017/jht.2012.3

Request Permissions : $\underline{\text { Click here }}$ 


\section{Critical Pedagogies: A Reflexive Approach to Knowledge Creation in Tourism and Hospitality Studies}

\author{
Simone Fullagar \\ Griffith Business School, Griffith \\ University, Australia
}

\section{Erica Wilson}

School of Tourism and Hospitality Management, Southern Cross University, Australia

\begin{abstract}
Being reflexive about the conditions and claims underpinning academic knowledge is a defining aspect of critical tourism and hospitality studies. In this article we explore how criticality has been conceptualised and consider the implications for addressing a major challenge in the field: that is, surfacing the power-knowledge relations that underpin mainstream or normalised ways of thinking. We aim to be reflexive about some of the dangers that exist in relation to the oppositional stance of critical perspectives. By drawing on examples from our own and others' critical research and teaching practices we examine how a reflexive approach can enable different types of dialogue, spaces and relationships. We draw on related work in critical management studies and debates within tourism and hospitality to argue for a critical pedagogy that embraces reflexivity as a 'practice' - a way of doing, thinking and transforming knowledge as we live it.
\end{abstract}

Keywords: critical tourism, reflexivity, critical pedagogy, tourism research, hospitality research
The central theme of this fournal of Hospitality and Tourism Management special issue was to explore the enduring relevance of critical tourism and hospitality studies. In this article we consider how critical perspectives often become polemic and entrenched in binary thinking (margin/centre, critical/positivist, theoretical/applied), which can limit the way in which we conceive of knowledge as a reflexive practice. We argue that the challenge ahead lies beyond the desire to simply occupy the dissenting position of the margins and also beyond a desire to become incorporated into 'mainstream' tourism and hospitality knowledge. Instead, we argue for multiple ways of problematising and engaging with disciplinary truths in tourism/hospitality that remain unreflexive about their own power-knowledge relations.

Critical traditions can be misunderstood, ignored or rejected by those who stand outside of them and dismissed by university institutions that assign value to more pragmatic outcomes that are framed in terms of industry relevance or hierarchical research values (such as journal rankings). Tourism and hospitality studies have no doubt gained legitimacy as academic domains within institutionalised university contexts, but this has also resulted in normalised ways of thinking, researching and teaching complex experiences. The institutional location of both tourism and hospital-

\section{Address for correspondence}

Simone Fullagar, Griffith Business School, Griffith University, 170 Kessells Road Nathan OLD 4111. E-mail: s.fullagar@griffith.edu.au ity is often within business schools with enterprising aims that embrace neoliberal, 'academic capitalist' ideas (Hall, 2010). While critical tourism and hospitality scholars have played a significant role in critiquing and questioning the effects of narrow conceptualisations of our fields of study and practice (Ateljevic, Pritchard, \& Morgan, 2007; Hall, 2004; Lugosi, Lynch, \& Morrison, 2009; Tribe, 2005; Wilson, Harris, \& Small, 2008), the challenge remains: how do we broaden the influence of the critical project to effect transformation through different academic spaces and practices?

Our article aims to explore how a reflexive position might open up opportunities different for knowledge practices in tourism/hospitality research and teaching. Indeed, to explore these opportunities we draw upon our own developing reflexive practices, or 'practical reflexivity' (Sinclair, 2007 b, p. 460) in teaching tourism and hospitality. We derive inspiration from Foucault's (1980) notion that intellectual work needs to continually problematise accepted truths (rather than simply proffer new truths). In this sense, the critical academic identity involves refusing who we are in order to become/create something else. It is a reflexive identity on a number of levels - individual, institutional and disciplinary - that acknowledges how powerknowledge relations 'govern' academic conduct (in classrooms, conferences, research assessment exercises, journal debates) in ways that reproduce or challenge normalised ways of knowing tourism and hospitality. How might we reflexively work within, across and against the grain of normalised thinking to engage those who are yet to think more critically about, or explore new ways of understanding the 
complex global and local challenges facing tourism and hospitality communities?

\section{Conceptualising 'Criticality'}

Within the emergent critical tourism and hospitality literature, there are divergent ways in which 'critical' is interpreted and practiced. Some critical scholars call for a postmodern and postdisciplinary criticality (Hollinshead, 2010), some for an academy of hope (Pritchard, Morgan, \& Ateljevic, 2011), while others yearn for a more pragmatic, critical realist approach (Botterill, 2007). Yet others are adamant that we must not forget the structural roots of oppression from which critical theory grew (HigginsDesbiolles, Powys Whyte, \& Mian, 2012), nor the material forces that continue to confine and constrain (Bianchi, 2009). The plurality of critical approaches is important for maintaining a vital intellectual space for reflexive debate within specialised 'critical' conferences and conference themes, as well as across different journals. However, there exists the danger that such debate will remain somewhat 'streamed' into special interest areas rather than be considered as core knowledge in tourism and hospitality.

The growth of the biennial Critical Tourism Studies conferences in the UK and Europe (2005, 2007, 2009, 2011) have been important, as well as special interest groups where a shared language has developed to foster the development of work in this area. The Critical Tourism Studies conferences, in particular, have generated a range of innovative approaches to thinking through the tourism experience as it is shaped by global and local forces, embodied through particular voices that are not often heard (older women, gay cruise passengers, local communities, travellers with disabilities) and written through the forces of affect or emotion as the underrecognised aspect of knowledge that exists beyond 'rationality'. In a different cross-sector conference context, such as the UK Leisure Studies Association (LSA) or the Australian and New Zealand Leisure Studies Association (ANZALS), tourism scholars have the opportunity to engage across related knowledge and practice domains in leisure, sport and events. These intellectual spaces enable sharing of similar critical approaches to different tourism-related problems and cross-fertilisation can offer new theoretical or methodological insights. Yet, the challenge remains concerning how critical scholars engage with and influence those who are yet to move into critical spaces or forms of dialogue? If we understand knowledge as a 'practice' and exercise of power that occurs through the written and spoken conversations that we have with many people in many ways, we can consider how we cut across divisions, conventions and disciplinary boundaries. As Hall (2010) argues, 'tourist academics are a sub-community of the social science community within the broader community of academics, scientists, and intellectuals which is itself a subset of wider society' (p. 298). If critical scholars are not talking across disciplinary and paradigmatic boundaries to engage others and our various audiences, then we run the risk of continual internal debate and discussion and of largely talking among ourselves. Ironically, this is the same critique that we aim at the mainstream.
One of the key challenges that we face in tourism and hospitality is working with more diverse understandings of criticality to move beyond assumptions that 'critical thinking' is primarily negative, polemic or totally incompatible with industry or government concerns. Critique that seeks primarily to identify the structural and economic form of injustice within globalised relations, to cut thorough ideology and identify new truth, is an important voice of dissent. However, this Marxist-inspired critique tends to serve a more singular purpose and drawing upon a structural notion of power can often fail to engage with the complex everyday power-knowledge relations that shape tourism and hospitality issues, institutions and networks. A narrow criticality can, ironically, alienate those comfortable in the mainstream. It can also run the risk of becoming unreflexive about the power-knowledge relations of its own critical truths and assumptions, which in effect may close down other possibilities for thinking and acting. Drawing upon a poststructural perspective we consider how structural forms of injustice are also profoundly cultural; tourism and hospitality issues, systems and practices are made thinkable through particular discursive repertoires and ways of governing the 'conduct' of others (Foucault, 1991).

Drawing upon Alvesson and Skoldberg's (2000) and Hollinshead's $(2010,2011)$ work, we posit here that the notion of reflexivity in a critical and creative sense may offer a way of thinking across boundaries, margins and beyond polarised positions. Reflexivity may offer a more relational, dialogical and transparent way to face these challenges and provide opportunities. Developing a more reflexive notion of critical tourism and hospitality raises a number of challenges in relation to the emphasis that is also needed on the creative and generative aspects of knowledge production and the relationship with industry and communities. The strength of tourism and hospitality studies lies in its multiplicity as a field, yet one of the dangers of maturing fields is stasis and reified truths about what is 'important' knowledge. Tourism and hospitality studies need to remain edgy by engaging with the development of ideas across many intersecting fields in the postdisciplinary era (Hollinshead, 2011). As Hollinshead (2011) explains, 'such forms of (postdisciplinary) critique tend to serve as dialectical opento-the-future inspections which uncover or account for the plurality of important . . . outlooks which have been overlooked, ignored or suppressed by dominant authorities ...' (p. 3).

If we look to knowledge practices that have emerged in the mobilities and 'slow tourism' literature, for instance, we see some current examples of how critical and creative ideas come together in reflexive ways of thinking about movement and relationships (Fullagar, Markwell, \& Wilson, 2012; Urry, 2002; Watts \& Urry, 2008). We can see how ideas related to the push and pull factors of tourism transform into understanding flows and networks, and how the notion of the host-guest relationship is reconfigured through ideas about the negotiation of power through difference and sameness in a globalising world. Further, consumer trends can be rethought in terms of shifting identities, desires and ethical relationships with the world (e.g., ecotourism, volunteer tourism, responsible tourism, dark tourism, gay tourism and slow tourism). 
Another key area that holds enormous potential to further reflexivity is the growth of nonwestern perspectives in both research and teaching practice. Critical tourism studies has engaged with theorising 'otherness' and exploring tourism relationships in terms of power differences. More recently, explorations of the epistemological basis of tourism theories have identified the dominance of a minority world-view and the need for greater cultural engagement in knowledge production (Winter, 2009). Another important dimension of critical tourism knowledge is considering different forms of praxis and documenting the changes that are created through reflexive research. One such example is the work that critical disability and tourism studies scholar Simon Darcy (Buhalis \& Darcy, 2011) has been doing with Tourism New South Wales to work with disability advocates, organisations and tourism bodies to create the website 'Sydney for All' (http://www.sydneyforall.com/AboutThisWebsite.html).

This critical project mobilises social justice through the creation of tourism information and opportunities for people with disabilities and more broadly. Such research helps shift the tourism gaze beyond normalised assumptions about how tourism is experienced and by whom.

\section{Critical Tourism/Hospitality Pedagogies and Reflexive Practices}

In developing our reflexive approach we draw specifically on a growing body of work associated with critical tourism and hospitality studies that has contributed to thinking about how we 'do' criticality in a multidisciplinary (and increasingly 'postdisciplinary') field (Ateljevic, et al. 2005; Pritchard, \& Morgan, 2007; Coles, Hall, \& Duval, 2006; Collins, 2002; Hollinshead, 2011; Tribe, 2008; Wearing \& Wearing, 2001; Winter, 2009; Wilson, Harris, \& Small, 2008). Importantly, this work foregrounded the development of a critical pedagogy, where scholars have been concerned with deconstructing the politics of tourism and hospitality knowledge in the classroom to include broader political, economic, cultural and social contexts (Hall, 2010; Hollinshead, 2010; Lugosi, Lynch, \& Morrison, 2009; Wilson, et al., 2008). To further this work we have drawn on critical perspectives within sociology, feminist theory and psychology, and also the emerging 'critical studies' work in more applied or professionally oriented disciplines such as education and management (Hooks, 2004; Fenwick, 2005; Sinclair, 2007a, 2007b). The critical management studies literature (e.g., Cockburn-Wootten \& Cockburn, 2011; Fulop, 2000; Sinclair, 2007a, 2007b) provides many insights that are useful for developing pedagogical practices in tourism and hospitality that can open up a diverse range of professional identities and more equitable teacher-student knowledge relations (Hooks, 2004).

Our own critical work is concerned with creating and sharing knowledge that we hope will have a positive effect on the world, our students, industry and government and each other. In relation to the pedagogical work of teaching tourism and hospitality, and designing curriculum with tourism colleagues, there exists the ever-present challenge of how to open up dialogue about thinking differently in an applied and theoretical sense. This task is made more chal- lenging in the highly governed and marketised higher education context where we are trying to engage students from very different cultural backgrounds and learning styles. Often there seems little room for theory or personal reflection in a tourism and hospitality curriculum crowded with specialist applied management knowledge (Ayikoru, Tribe, \& Airey, 2009; Dredge et al., 2010; Tribe, 2002). Hence, critical scholars are interested in revealing the act of teaching and learning as political processes and the impacts of their own teaching on their lives as well those of their students (Hooks, 2004). As Belhassen and Caton (2011) argue, critical scholars 'envision an alternative to the traditional curriculum, in which students learn not just how to be effective managers in the current tourism system, but also how to think about management as a social force' (p. 1392). Critical forms of pedagogy aim to radically reconfigure the traditional model of teacher-focused learning, where the teacher is the universal purveyor of knowledge and the students are passive recipients (Cockburn-Wootten \& Cockburn, 2011; Cooper \& Kulisa, 2003). In relation to tourism and hospitality, one of the pedagogical challenges of teaching students (whom we hope will be our future leaders) is how to develop a reflexive sense of identity that is both academic/conceptual and professional/applied.

Despite the different constructions of tourism and hospitality pedagogy there is at least a common discourse within all universities about the value of teaching students to 'think critically'. In fact, critical thinking is identified within our respective institutions as a core 'graduate attribute' (e.g., graduates should be 'Innovative and creative, with critical judgement' or learn to be 'Critical thinkers'). Many of our course outlines, developed by academics across the spectrum, claim to teach critical thinking skills in the applied management context of tourism and hospitality. While the issue of how we deploy the concept and practice of criticality can vary, the term does provide a starting point for exploring what critical practices mean in the embodied space of teaching and within the discursive parameters of the curriculum. While it may be accorded greater or lesser 'value', the language of critical thinking informs the institutional construction of tourism and hospitality student-graduate-professional identity and creates a space for articulating different knowledge practices. Critical reflection may thus involve questioning the process of teaching, or the development of curriculum or assessment that unsettles disciplinary norms about 'managing tourism and hospitality' (such as oppression, race/racism, women and feminism, gay/lesbian experiences, Indigenist and disability studies, and so on). What real relevance, we are asked, do these areas of enquiry have for the tourism and hospitality industry at large? What practicalities and real opportunities for action exist? These are valid questions to ask of critical scholars and our response is twofold; questions about inequity are fundamental to understanding tourism and hospitality experiences and developing reflexive management responses that are premised on an understanding of power and ethics.

We may also wish to question the way the identity of the tourism and hospitality industry is constructed in academic discussion over curriculum content and the achievement of graduate outcomes with industry relevance. There 
is a danger in perpetuating a rather homogenised notions of 'an industry' that is comprised of like-minded organisations and consumers. A critical perspective acknowledges the incredible diversity that characterises the industry with very different organisational agendas, triple bottom line concerns and ways of operating, while emphasising common problems, issues and areas for development. Interestingly, there have been recent calls from the Business Council of Australia for business graduates who have developed broad professional skills and expertise (e.g., crosscultural communication, team work) that align well with a reflexive approach to tourism and hospitality management. Critical thinking appears to be making a resurgence within broader industry discourse, as this recommendation about graduate outcomes stipulates, 'the ability to think independently, to critically analyse issues and problems, and to adapt thinking and analytical capabilities to different contexts and new problems' (Business Council of Australia, 2011, p. 4).

Building on the renaissance of critical thinking within business education we see a real strength in many tourism and hospitality programs being 'work-integrated learning' (WIL) experiences. WIL creates opportunities for students to explore critical perspectives within an applied industry context and importantly, develop skills in reflexive thinking (Caldicott, 2010; Lashley, 1999). The first author reflects on the nexus between industry context, professional skills and reflexive learning in her experience of teaching within a work-integrated learning program.

Students bring to the classroom each week a rich array of practicum experiences, including emotional responses and insightful observations about organisational values and practices. They are required to write a reflective journal to help them "notice" and articulate the dynamics and norms of the workplace that can often appear "natural", inevitable or just the "way things get done around here". However, what appears to be most powerful is the practice of sharing those experiences with each other in a classroom where learning is facilitated (as distinct from an instructional style). Students develop an amazing capacity to analyse the everyday dynamics of power, the effects of effective and ineffective leadership styles, along with organisational responses to key issues such as cross-cultural understanding, shifting markets or climate change. The structured learning context provides a space for reflection where the industry context can be suspended, examined and students own professional dilemmas explored in terms of the skills and knowledge they wish to develop further. Discussions often focus on ethics and values in relation to the type of tourism or hospitality professional the student desires to become. In this way we are able to foster a reflexive awareness of how they are positioned professionally and personally within a broader industry context and organisational agendas.

In addition to work-integrated learning opportunities, tourism and hospitality courses can embrace critical pedagogies through the notion of reflexive 'praxis' (Brookfield, 1995). By bringing theory and practice together in applied management and everyday contexts these different forms of knowledge enable students to consider how they make sense of and respond to key issues of the times. Both authors reflect below on the ways in which praxis has been used to promote reflexive learning with regard to teaching at their respective institutions:

(Simone): Within my institution, we try to do this in our first-year Foundation Studies course where students undertaking most of our majors (sport, tourism, hotel and event management) learn through different social science perspectives (sociology, psychology, economics, geogra- phy) in relation to these diverse sectors and management contexts. We build in opportunities to reflect on the practicalities of working/learning in a culturally diverse context by emphasising the value of group work and constructive communication. Students find it challenging to have to work together to understand each other and understand a leisure-related phenomenon of their choice. Through lecture material and assessment we position tourism and hospitality as industries in the world and objects of academic knowledge that exist within a broader social context of leisure experience and leisure industries. In this sense, leisure includes tourism, hospitality, events, sport, the arts, outdoor and home-based recreation as they are all connected as goods or services, private or public spaces, that individuals consume, participate in or experience in the context of global capitalism. Students complete an assessment task that involves a group observation and analysis of a leisure space of their choice (e.g., hotel lobby, sport event or public park). They bring together their different cultural interpretations and social science perspectives to understand the leisure phenomenon. They explore for whom, what and how the leisure experience occurs (and through critical observation, which groups and individuals are missing?). By undertaking this everyday analysis as a group students develop a range of skills that will help them in future management roles - listening, observing what is apparent and what is not, applying theoretical perspectives to the world they see, communicating and problem-solving. Having completed their Foundation Studies course our students can then continue to develop their reflexive knowing within their specific management context.

(Erica): The idea of praxis as it relates to my undergraduate Sustainable Tourism class is that there is a merging between practice and theory. In my own reflective practice, I felt I had become too focused on telling students about the theories and debates inherent in sustainable development/tourism. Trying to employ a critically reflective approach, I turned this around and started instead from the students' experiences. I assumed that students would better understand issues like limits to growth, sociocultural impacts and the modern environmental crisis and so on if they could relate them to their own lives. This fits with Biggs and Tang's (2007) notion of "constructive alignment", which implies that learners will only understand if they can apply information through to their own experiences and contexts. Indeed, Stephen Brookfield (2005) notes that critical theorising is not something that happens solely within the confines of the university. In applying critically reflective practice to understand tourism, we should be effectively speaking of and to our everyday worlds. Thus I made a deliberate choice in one of the assessment items, grounded in and supported by critical pedagogy, to ask for and welcome the first-person voice and to allow students to write about issues as they affected them.

As these reflective pedagogical examples help to demonstrate, tourism and hospitality can no longer simply be construed as service economies, but rather part of what Pine and Gilmore (2011) refer to as the 'experience economy'. With some tourism and hospitality programs in Australia experiencing decline in student enrolments, there is potentially a 'discursive space' opening up for a more reflexive and creative approach to curriculum development that explores the complexity of experiences and relationships. People seek to transcend some aspect of the banality of everyday life and create identity through a variety of tourism/hospitality experiences that they consume or provide. As future leaders, students need diverse theoretical and applied knowledge to help understand the complexity of tourism and hospitality experiences in a globalised, webmediated, rapidly changing world (Ayikoru, Tribe \& Airey, 2009; Cockburn-Wootten \& Cockburn, 2011; Dredge et al, 2010). Indeed, Belhassen and Caton (2011) surmise that 'broadening tourism curricula ... essentially invites dialogue about values, power interests, and desirable ends back into the conversation, thus allowing students to reflect critically, as free thinkers, on the kind of world they want to build' (p. 1392). As teachers and researchers we need to 
reflexively draw upon the domains of social sciences, humanities and management to understand and respond to emerging consumer desires and market trends, as well as the range of challenges we face with respect to social, cultural, environmental and environmental changes (Tribe, 2002; von der Heidt \& Lamberton, 2011; Wilson, 2010; Wilson, Harris, \& Small, 2008). Simone reflects upon these challenges in the context of teaching a leadership course to students within an undergraduate tourism and hospitality management program in Hong Kong,

Teaching leadership in a cross-cultural context is challenging on many levels for both the students and myself. I don't actually believe that I can teach them to become "good leaders" but I can teach them how to think reflexively about the concept and practice of leadership as they make decisions about their tourism and hospitality careers. We start by "deconstructing" our assumptions about what constitutes a good leader in relation to cultural norms and we explore the way ideas about leadership have changed in the literature. Using experiential learning activities that students enjoy, we also reflect on the dynamics of leadership in action. These different knowledge practices enable students to draw upon their different learning styles and to identify their own values and leadership preferences. They are very quick to discern the power differences evident in "transactional" and "transformational" leadership approaches in the context of their previous professional experiences and organisational hierarchies. Several topics resonated strongly with students - interpersonal communication, understanding diversity, working with teams and resolving conflict. They are indicative of the ethical dilemmas around power and the emotional labour of leadership that is often underrecognised in tourism and hospitality roles. Teaching this course requires my own reflexive engagement in questions about how we negotiate the exercise power within universities. The broader changes in higher education that emphasise standardisation, new quality measures and continual restructuring have an embodied effect on academics; sapping the creative energy of many and the sense of agency so necessary to enabling change. What has informed my thinking and pedagogical practice has not just been my disciplinary base in sociological ideas; importantly, it has been my reading of new approaches to leadership that has enabled a way of thinking about engagement, purpose and commonality (for example, Rock, 2007; Sinclair, 2007a). Reflexive approaches to teaching are embodied and relational, they generate energy that can enable change and creativity in a highly regulated learning context.

Another critical issue to which our institutions must respond, particularly given the increasing importance around 'corporate social responsibility and sustainability', will be that of diversity and social inclusion. How do we educate tourism and hospitality students to understand the diverse experiences of women, people from different cultures, older persons, people with disabilities and Indigenous Australians in the context of tourism consumption and management? Evoking public discourses on diversity or sustainability can lend legitimacy and open the door to the 'critical project' in teaching and learning without necessarily evoking antagonism. The gaps often stare us in the face, but remain somewhat invisible to those comfortable in the mainstream. Because it questions our values, beliefs and assumptions, critical pedagogy does have the potential to move both us and our colleagues out of the 'comfort zone' (Brookfield, 1995). We need to be able to find ways to work with others, address fears of change or 'not' knowing, in order to practice reflexivity in our everyday teaching and learning.

\section{Conclusion}

As the title of this article initially asked: how can we develop a reflexive approach in critical tourism and hospitality studies that moves beyond polarised debate or antagonism? As we have argued in the discussion above, critical scholars cannot risk fading away, waiting for the revolutionary overthrow of the 'managerialist regime'. A reflexive analysis of the gaps and opportunities, as well as the blocks and strategic agendas, within our institutions can energise us to find the critical way through. In this article, we drew on a number of reflexive examples - from both research and teaching - that serve to demonstrate some of the challenges and opportunities inherent in moving beyond the margins. Perhaps the main conclusion from this article is that as critical tourism and hospitality scholars, we must continue to keep open a relational dialogue with 'the mainstream', in an effort to remain reflexive and open to other truths and realities. We want the critical project to be given credence in light of the greater emphasis on critical thinking and professional skill development in business education by industry representatives. Within tourism and hospitality studies, relational dialogue about what criticality means is a way to think beyond the existing methodological, paradigmatic and institutional power barriers currently at play.

At the same time, this does not mean that we abandon our critical beliefs and values or the need for an oppositional stance on key issues. It also does not mean that we either wish to appeal to, or appease, the mainstream. The aim here, in a postdisciplinary vein, is to use our 'soft power' to remain open to the future, open to dialogue and debate and to ensure that as critical scholars, we do not become entrenched in our views and unable to welcome others' (Coles, Hall, \& Duval, 2006; Hollinshead, 2010). In arguing for more divergence and diversity, we do not want to lose our critical 'roots'; issues of oppression, constraint, disability, racial inequality must and will always remain central and deserve criticism as long as they are ignored and examined unreflexively by those in the mainstream. What we do value most in the critical project is the diversity of ways of understanding the operation and effects of power, both oppressive and hopeful.

\section{References}

Alvesson, M., \& Skoldberg, K. (2000). Reflexive methodology: New vistas for qualitative research. London: Sage.

Ateljevic, I., Harris, C., Wilson, E., \& Collins, F.L. (2005). Getting 'entangled': Reflexivity and the 'critical turn' in tourism studies. Tourism Recreation Research, 30(2), 9-21.

Ateljevic, I., Pritchard, A., \& Morgan, N. Eds. (2007). The critical turn in tourism studies: Innovative research methodologies. Oxford: Elsevier.

Ayikoru, M., Tribe, J., \& Airey, D. (2009). Reading tourism education: Neoliberalism unveiled. Annals of Tourism Research, 36(2), 191-221.

Belhassen, Y., \& Caton, K. (2011). On the need for critical pedagogy in tourism education. Tourism Management, 32, 1389-1396.

Bianchi, R.V. (2009). The 'critical turn' in tourism studies: A radical critique. Tourism Geographies, 11(4), 484-504.

Biggs, J., \& Tang, C. (2007). Teaching for quality learning at university (3rd ed.). Berkshire, UK: McGraw-Hill/The Society for Research into Higher Education. Maidenhead: Open University Press/McGraw Hill.

Botterill, D. (2007). A realist critique of the situated voice in tourism studies. In I. Ateljevic, A. Pritchard, \& N. Morgan (Eds.), The critical turn in tourism studies: Innovative research methodologies (pp. 121-131). Oxford: Elsevier. 
Brookfield, S. (2005). The power of critical theory for adult learning and teaching. Berkshire, UK: Open University Press.

Brookfield, S. (1995). Becoming a critically reflective teacher. San Francisco: Jossey-Bass.

Buhalis, D., \& Darcy, S. (2011). Accessible tourism: Concepts and issues. Bristol, UK: Channel View.

Business Council of Australia. (2011). Lifting the quality of teaching and learning in higher education. Melbourne. Australia: Author.

Caldicott, J. (2010). Fitting the critical reflection training wheels prior to the WIL journey - embedding preparation into the tourism and hospitality curriculum. In M. Campbell (Ed.) Work Integrated Learning Responding to Challenges: Proceedings of the 2010 ACEN National Conference, Curtin University, Perth, September 29-October 12010 , 45-56.

Cockburn-Wootten, C., \& Cockburn, T. (2011). Unsettling assumptions and boundaries: Strategies for developing a critical perspective about business and management communication. Business Communication Quarterly, 74(1), 45-59.

Coles, T., Hall, C.M., \& Duval, D.T. (2006). Tourism and post-disciplinary enquiry. Current Issues in Tourism, 9(4), 293-319.

Collins, A. (2002). Are we teaching what we should? Dilemmas and problems in tourism and hotel management education. Tourism Analysis, 7, 151-163.

Cooper, T., \& Kulisa, J. (2003, July 7-9). Critical pedagogy and teaching management in university: Examining the possibilities and limitations. Paper presented at the Third International Conference on Critical Management Studies, Lancaster, UK.

Dredge, D., Benckendorff, P., Day, M., Gross, M., Walo, M., Weeks, P., \& Whitelaw, P. (2010). Conceptualising the perfect blend in the tourism and hospitality curriculum space. In M.J. Gross (Ed.), Proceedings of the CAUTHE Conference, 'Creating the Perfect Blend in Tourism and Hospitality Education' (p. 1-20). University of South Australia, Adelaide, February 8-11.

Fenwick, T. (2005). Ethical dilemmas of critical management education: Within classrooms and beyond, Management Learning, 36(4), 3148.

Foucault, M. (1980). Power/knowledge: Selected interviews and other writings 1972-1977. Hemel Hempstead, UK: Harvester Wheatsheaf.

Foucault, M. (1991). Governmentality (R. Braidotti, Trans.). In G. Burchell, G. Gordon, \& P. Miller (Eds.), The Foucault effect: Studies in governmentality (). Hemel Hempstead, UK: Harvester Wheatsheaf.

Fullagar, S., Markwell, K., \& Wilson, E. (2012). Slow tourism: Experiences and mobilities. Bristol, UK: Channel View Publications.

Fulop, L. (2000). Practicing what you preach: Critical management studies. Organization, 9(3), 428-426.

Hall, C.M. (2004). Reflexivity and tourism research: Situating myself and/with others. In J. Phillimore \& L. Goodson (Eds.), Qualitative research in tourism: Ontologies, epistemologies and methodologies (pp. 137155). London: Routledge.

Hall, C.M. (2010). Academic capitalism, academic responsibility and tourism academics: Or, the silence of the lambs? Tourism Recreation Research, 35(3), 298-301.
Higgins-Desbiolles, F., Powys Whyte, K., \& Mian, A. (2012, February 69). Abandon hope: The importance of remaining critical. Paper presented at the 22nd Annual CAUTHE conference, Melbourne.

Hollinshead, K. (2010). Tourism studies and confined understanding: The call for a new sense postdisciplinary imaginary. Tourism Analysis, 15(4), 499-512.

Hollinshead, K. (2011, February 8-13). 'Soft power' in action: The new or old? - declarative diplomatic function of tourism. Paper presented at the CAUTHE conference, University of South Australia, Adelaide, SA.

Hooks, B. (1994). Teaching to transgress: Education as the practice of freedom. New York: Routledge.

Lashley, C. (1999). On making silk purses: Developing reflective practitioners in hospitality management education. International fournal of Contemporary Hospitality Management, 11(4), 180-185.

Lugosi, P., Lynch, P., \& Morrison, A. (2009). Critical hospitality management research. Service Industries fournal, 29(10), 1465-1478.

Pine, J., \& Gilmore, J. (2011). The Experience Economy (2nd ed.). Massachusetts: Harvard Business School

Pritchard, A., Morgan, N., \& Ateljevic, I. (2011). Hopeful tourism: A transformative approach. Annals of Tourism Research, 38(3), 941-963.

Rock, D. (2007). Quiet leadership. New York: Harper Collins.

Sinclair, A. (2007a). Leadership for the disillusioned: Moving beyond myths and heroes to leading that liberate. Sydney, Australia: Allen and Unwin.

Sinclair, A. (2007b). Teaching leadership critically to MBAs: Experiences from heaven and hell. Management Learning, 38(4), 458-472.

Tribe, J. (2002). The philosophic practitioner. Annals of Tourism Research, 29(2), 338-357.

Tribe, J. (2005). New tourism research. Tourism Recreation Research, 30(2), 5-8.

Tribe, J. (2008). Tourism: A critical business. Fournal of Travel Research 46(3), 245-255.

Urry, J. (2002). Mobility and proximity. Sociology 36(2), 255-274.

von der Heidt, T., \& Lamberton, G. (2011). Sustainability in the undergraduate and postgraduate business curriculum of a regional university: A critical perspective. Fournal of Management and Organization, 17(5), 670-690.

Watts, L., \& Urry, J. (2008). Moving methods, travelling times. Environment and Planning D: Society and Space, 26, 860-874.

Wearing, S., \& Wearing, B. (2001). Conceptualizing the selves of tourism. Leisure Studies, 20(2), 143-159.

Wilson, E. (2010, February 8-11). Practice what you teach: Using critically reflective practice in teaching sustainable tourism planning. In S. Crispin, A. Dunn, S. Fishwick, A. Franklin, D. Hanson, D. Reiser, R. Shipway, M. Wells, \& C. Baxter (Eds.), Proceedings of the 20th Annual Conference, Council for Australian University Tourism and Hospitality Education (CD Rom). Hobart, Tasmania: CAUTHE.

Wilson, E., Harris, C., \& Small, J. (2008). Furthering critical approaches in tourism and hospitality studies: Perspectives from Australia and New Zealand. Fournal of Hospitality and Tourism Management, 15, 15-18.

Winter, T. (2009). Asian tourism and the retreat of anglo-western centrism in tourism theory. Current Issues in Tourism, 12(1), 21-31. 